Отримано: 12 січня 2020 року

Прорецензовано: 23 січня 2020 року

Прийнято до друку: 29 січня 2020 року

e-mail: t.kuptsova@ukr.net

irinakolieva79@gmail.com

DOI: 10.25264/2519-2558-2020-9(77)-43-46
Kuptsova T. A., Koliieva I. A. Structural peculiarities of railway term formation in the English language. Наукові записки Національного університету "Острозька академія»: серія «Філологія». Острог: Вид-во НаУОА, 2020. Вип. 9(77). С. 43-46.

\author{
Tetiana A. Kuptsova, \\ Associate Professor, PhD in Philosophy \\ Dnipro National University of Railway Transport named after \\ Academician V. Lazarian \\ Iryna A. Koliieva, \\ Associate Professor, PhD in Philosophy \\ Dnipro National University of Railway Transport named after \\ Academician V. Lazarian
}

\title{
STRUCTURAL PECULIARITIES OF RAILWAY TERM FORMATION IN THE ENGLISH LANGUAGE
}

\begin{abstract}
The structural peculiarities of the railway term formation is investigated in the article. It is demonstrated that the most common ways of the one component railway term formation are suffixation and prefixation. The prefixation-suffixation type is a less productive way of the word building. Compound words proved to form a large group of the railway terms. The relations among the components of a compound word represent a specific type of semantic and structural relations of the word in a word combination, where the terms which consist of «noun+noun», "adjective+noun» predominate. In the system of the English railway terminology among the component terms the most widespread are nouns that explains that nouns define processes, equipment, devices, and objects. This paper outlines some linguistic properties of technical terms. The article focuses on some linguistic features of a term. Being a linguistic object with the common and specific features of a language system a term has all lexical-semantic and formal features of the words and word combinations of a natural language. In the process of the affixation term building the semantics of a derived word is defined by an affix that is why an affix can bear a particular word building meaning. But having definite motivational relations between a derivative and a derived word the semantics of the derived word is not always determined by the meanings of its components. Deciding the semantics of a derived term many factors should be taken into consideration: conversion, the peculiarities of a compound word, polysemy etc. It should be underlined that morphological or affixation type of the term forming is based on the principles of word building of the literary language.

Key words: term, railway terminological system, lexical unit, compound words, suffixation, prefixation, compound words, conversion, word building.
\end{abstract}

\author{
Купцова Тетяна Анатоліївна, \\ кандидат філософських наук, доиент \\ Дніпровський національний університет залізничного транспорту імені академіка В. Лазаряна \\ Колісва Ірина Анатоліївна, \\ кандидат філософських наук, доцент \\ Дніпровський національний університет залізничного транспорту імені академіка В. Лазаряна
}

\section{СТРУКТУРНІ ОСОБЛИВОСТІ УТВОРЕННЯ ЗАЛІЗНИЧНИХ ТЕРМІНІВ В АНГЛІЙСЬКІЙ МОВІ}

У статті досліджуються структурні особливості творення залізничних термінів в англійській мові. Доведено, щяо найбільш поширеними способами творення однокомпонентних залізничних термінів є суфіксація та префіксація. Менш продуктивним способом виступає префіксально-суфіксальний спосіб словотворення. Вагому групу представляють складні слова, в яких відношення між компонентами представляють особливий вид семантичних та структурних відношень слова в словосполученні. Найпоширенішу групу серед складних слів становлять слова, щуо складаються з «іменник+іменник», «прикметник+іменник». В системі залізничної термінології найчисленнішу групу серед однокомпонентних термінів становлять іменники, щчо пояснюється тим, цио іменники є назвами процесів, обладнання, пристроїв, предметів.

Ключові слова: термін, термінологічна система залізничного транспорту, лексична одиниця, складні слова, суфіксація, префіксачія, конверсія, словотворення.

Introduction. It is widely acknowledged to determine the trends of the development of modern linguistics and it is essential to be aware of the processes of modeling of the word origin in specific subject matters. Any field of knowledge can not dispense with its own terminology nominating its concept. Study of the term formation is a priority area of the modern terminology.

Theoretical background. As it is stated by the linguists the primary reason for the study of terminology was both self-acting, like the reason for technology, and theoretical, like the reason behind the beginning of science. During the synchronous knowledge increase and the technology growth and communications stretching in the eighteenth century, terminology was seen as «a necessary tool for overcoming some of the difficulties associated with these multiple developments» [8, p. 2]. It should be noted that in the twentieth century terminology has received a scientific character while simultaneously being identified as some socially essential activities. The specialists note the terminology as the discipline referred to as the study and composition of specialized terms is not a new branch of study, but only recently has it been methodically evolved, with complete reflection of its rules, bases and methods. Its social and political significance has also now been realized on both the international and the national level [8, p.4]. 
In accordance with generally accepted definition a term is a sign of the special semiotic system that performs the function of definition to express a concept. It is a complex dialectical phenomena, which combines inherently coexisting language substrate and logical superstrate of a term, and its own terminological nature (scientific, scientific-technical) meaning [3, p. 74]. The scientists say that the word terminology refers to at least three different notions. Firstly, there are the principles and conceptual foundations that influence the terms study. Secondly, there are the general rules which are used in the study of terminology, and thirdly, there is the series of terms of a separate special topic [8, p. 6]. It can be pointed out that in its primary meaning, terminology is commonly understood as an interdisciplinary branch that refers to «the naming of concepts of particular subjects, and their realization in linguistic or other forms» [8, p. 7].

Therefore, there is no individual scientific approach to terminology, but few ones. According to the extended opinion the three most vital approaches are: speaking about linguistics terminology is a part of the particular lexicon that is distinguished by subject and pragmatic features; speaking about scientific-technical disciplines terminology is the formal consideration of their conceptual structure and a basic means of expression and communication; speaking about the user terminology is «a set of useful communicative units which must be evaluated from the point of view of economy, precision and suitability of expression» [8, p.12].

A term represents a real linguistic object with the common and specific features of a language system. It has all lexical-semantic and formal features of the words and word combinations of a natural language. A term refers to a part of speech; it has wordformative and word-changeable potential, paradigmatic and syntagmatic properties and features. As a term has a language origin, it refers to a certain language to determine a special notion (scientific, scientific-technical), and it refers to definite systems of terms (lexical-semantic field). Being a system unit of a particular lexical semantic field, a term engages in the system of the paradigmatic syntagmatic relations with other terms and also with the parts of scientific and literature language $[4,11]$.

The term science has acknowledged that a term is intended not only to express the scientific concept but to be a unique instrument of cognition and knowledge.

Comparing the terms and other words it should be underlined that the former ones have such peculiarities as follows: accuracy, unambiguity, independence from the context. An important feature of a term, especially in the scientific-technical literature, is absence of emotional issue. But some scientists emphasize that the linguistic style of the English scientific-technical literature «accepts» some imagery which there is no in the Ukrainian texts. We cannot but agree with G. Yatel that the scientific-technical terminology (including the railway one) is different [7, p. 212]. It includes:

1) a considerable number of commonly-used words, which in addition to their main meaning have a specific (terminological) meaning. For example, a widely used word field (an area of land) in computer science means a space where you can type information in computer program, in sport it is the team throwing ball, in basic science it has the meaning of a subject one studies or type of work, while in railway terminology it is a magnetic flux induced by electricity flowing through the field coils and some others;

2) general technical terms used in several branches of science and technology. For example, commutator: in electricity - a device for reversing the direction of a current or a cylindrical ring or disk assembly of conducting members, individually insulated in a supporting structure with an exposed surface for contact with current; in mathematics - the element equal to the product of two given elements in a group multiplied on the right by the product of the inverses of the elements;

3) special terms belonging only to one field of science or technology. For example, axle is a supporting member that carries a wheel and rotates with the wheel to transmit mechanical power to or from it, or allows the wheel to rotate freely on it.

The object of our investigation is the study of the basic methods of forming of the railway terms in the English language. The following questions guided the study:

- to determine common peculiarities and the functions of a term in the scientific language;

- to identify the main requirements to this group of the words;

- to investigate which affixes predominate in the railway term building;

- to determine the relations among the components of a compound term.

The analysis of the latest research. For many years scientists (S. V. Griniov, V. A. Tatatinov, G. P. Yatel, V. M. Leichik, V. P. Danilenko, Cabré M. Teresa, H. Marchand and others) have made the attempts to classify the main ways of the forming of the new terms. To sum up their investigations the following structural ways of term forming should be pointed out: the semantic one (when a word or a word combination of a common language is used as a term); the morphological way (a term forming with the help of affixes); the morphologo-syntectical one (a new term is built by compounding of two stems); the syntactical one (that is forming of a term with the help of cutting the stems of the words). S. V. Griniov underlines that the most productive way of the term formation is the syntactical one, as compound terms prevail over one-word terms. The scientist writes that investigating the European languages he came to the conclusion that 60-90 per cent of the modern terms are formed by compounding words to produce a new meaning [2].

Methods. In the research process of the formation of the railway terminology we applied the method of general scientific dialectical approach of cognition, component analysis, and analytical approach.

Results and Discussion. It is recalled all terminological systems, including the term system of railway terms, consist of lexical units of two main types: one-component and multi-component terms. Derived railway terms are formed by means of some typical English word-forming models: with the help of prefixes (discharge), suffixes (suspension), prefixes and suffixes (semiconductor). It should be underlined that suffixes and prefixes do not play the same part in the word building process. In most cases suffixes are engaged in forming one part of speech from the other. Prefixes, on the contrary, form one part of speech from the other only sometimes. Generally they form new words of the same part of speech: connect-disconnect.

The most active prefixes used in forming the railway noun and adjective terms are

after- - afterburning, aftercooler, afterdripping;

anti- - проти-: antiknock, antirattler, antidrum, antifriction,

de-- де-, роз-: decoupling, decrease, debarkation, debooster, decelerate, defoffing, deformeter, depressed, derailing;

dis- - po3-: disabled, disadjust, disalignment, disassemble, discharge, disconnectable, disjoin, displacement, disused;

inter- - між-, взаємо-: intercity, intercooler, interlayer, interleaves, interlinkage, interlock, interpolation, interspace, intertie;

mis- - не- (заперечне значення): misadjustment, misalignment, misconnection, misfire, mishandling, misoperation, misregulation, misrouting; 
over- - понад-; пере-: overbalance, overcharge, overcome, overcurrent, overdrive, overdue, overhead, overfire, overhang, overhauling, overload, overmounted;

re- - пере-, повторюваність: rearrangement, reassembly, reballasting, rebed, rebushing, reclosure, recoil, reconnection, recoupling, redistribution, remover;

sub- - суб-, під-, нижче-: subassembly, subbalast, subdivision, subframe, subgrade, subpanel, subsidiary, subsize, substation, subway;

super--пере-, понад-, над-: superstreamlined, supercharger, superelevated, superfast, superheating, superintendent, superpower, superstructure;

trans- - транс-, пере-: transborder, transformer, transship, transposed;

un- - не-; роз-, без-: unattackable, unattended, unbalanced, unblanking, unblock, unbroking, uncharge, uncouple, uncovered, undamped;

under- - під-: underdriven, underbraced, undercapacity, undercarriage, undercurrent, underdrive, underframe, underlayer, undersetting.

Having analized the word-forming prefixes of the railway terms we came to the conclusion that prefixes: bi-, co-, extra-, ultraare less productive:

bi- - biaxial, bicurvature, bidirectional, bifuel, bifurcation;

extra- - понад-: extrafast, extraheavy, extrahigh, extratrain, extratruck;

ultra- - понад: ultrasonic.

In the morpheme structure of the nouns of railway terms there are such suffixes as -tion (usually added to a verb to form a noun), -or, -er, -ing, -sion, -ment, -ance, -ure, -ry, -ty:

-tion: acceleration, containerization, friction, junction, motion, obliteration, vibration, motion, suspension;

-or: accumulator, generator, actuator, compressor, alternator, rotor, conductor, radiator, motor;

-er: amplifier, choker, pier, girder, buffer, cantilever, retarder, commuter, converter, fastener;

-ing: coupling, braiding, bearing, cowling, packing, dimming, gearing, binding, buckling;

-sion: abrasion, adhesion, transmission, suspension, collision, accumulation, catenation;

-ment: abutment, alignment, arrangement, abolishment, adjustment, movement, compartment, treatment;

-ance: allowance, adherence, conductance, coherence, resistance, maintenance

-ure: armature, admixture, curvature, pressure, substructure;

-ry: battery, catenary;

-ty: capacity, ability, accessibility, capability, safety, irregularity density, velocity.

Analyzing the term adjectives we came to the conclusion that they are also widely used to modify equipment, machinery, technics, devices and technical processes. The productive suffixes of the word-forming adjectives include the following ones:

-al - additional, axial, vertical, manual, helical;

-ive - adhesive, conductive, permissive, selective, abrasive;

-able and -ible - adjustable, movable, accessible, admissible;

-ic - automatic, electric, specific, dynamic, magnetic;

-ary - auxiliary, accessory, subsidiary $[1 ; 6]$.

Compound technical terms are formed by means of the compounding morphological method of word building when two or more words are linked together to form a new meaning. As a rule the roots are free morphemes. It means that compound words are formed of the independent words in such case: crosstie, flagman, flywheel. A compound word is formed of the word stems which are in particular structural and semantic relations. The relations among the components of a compound word represent a specific type of semantic and structural relations of a word in a word combination. But the feature of an object or phenomenon is identified differently while determining and denoting it. According to their structure such types of words are close to the word combinations as they consist of the combinations of the words. Regardless to their form (some of the terms are written as one word, others with a hyphen) compound terms keep their semantic form. In compound words the main semantic stress is on their last element and they have the subordinate semantic link between the compounds. Marchand underlines that all compound words can be explained through their syntactic relations underlying in their stem [9, p. 254-267].

Analyzing compound railway terms it should be underlined that the model with a noun as a second component is the most widespread in the English railway terminology: axlebox, gearbox, railway, swing-motion. The model $\mathrm{N}+\mathrm{N}$ is widely used in railway compounds: barframe, baseplace, bachbox, wheelbase, brakeblock, cargotainer, carhouse, handrail, flangeway. The model $\mathrm{A}+\mathrm{N}$ : deadline, freeway, sunk-screw, single-arm, semaphore arm is also productive one.

Conversion (word building without affixes) is also used in word building of the technical terms. New terms are formed without changing basic forms of the words, which they derived from. In other words a word form is transferred into another lexicomorphological group (another part of speech) and acquires all lexico-grammatical principal features (paradigm) of a new part of speech, but with the same lexical meaning [7, p. 218]:

brake $\mathrm{n}$. a machine element for applying friction to a moving surface to slow it down or bring it to rest;

brake $\mathrm{v}$. to slow or stop by pressing against the wheel;

tie $n$. a beam that holds two rails a set distance apart and provides a wider footing for tracks;

tie $\mathrm{v}$. to fasten together two ends of long rails;

switch $\mathrm{n}$. a device for enabling railway car to pass from one track to another;

switch $\mathrm{v}$. to move by using a switch;

speed $\mathrm{n}$. fast movement of traffic;

speed $\mathrm{v}$. to move or go fast;

wheel $\mathrm{n}$. a circular frame with a hub at the center for attachment to an axle, about which it may revolve and bear a load;

wheel $\mathrm{v}$. to move an object with wheels under it $[1 ; 5 ; 6]$. 
Conclusion. As it was mentioned above the terms are the parts of a definite terminological system of a language. Being a component part of the language vocabulary the terms express a specific meaning, that characterizes a narrow professional or scientific area, its definitions, concepts and meanings. That is why it should be underlined that the function of a term in the scientific and technological texts provides a precise definition of the real objects and phenomenon determining monosemantic understanding of the definite information by the specialists. Hence a range of requirements to this group of the words is the following: 1 . A term must have a defined meaning; this feature determines its place in a system of a scientific and technical field. 2 . A term must have a monosemous meaning. 3. One term should correspond to one meaning. We cannot help agreeing with the scientists who consider that figurative meaning, that is often connected with the root of the word, does not play any independent connotative part in the scientific and technical texts.

The investigation have provided evidence that the most common ways of the one component railway term formation are suffixation and prefixation. The prefixation-suffixation type is less productive way of the word building. Compound words proved to form a large group of the railway terms. The relations among the components of a compound word represent a specific type of semantic and structural relations of the word in a word combination, where the terms which consist of «noun+noun», «adjective+noun» predominate. In the system of the English railway terminology among one component terms the most widespread are nouns, that is explained that nouns define processes, equipment, devices, objects.

It is quite obvious that knowledge of the structural peculiarities of terms is significant issue as it provides an opportunity to predict the further development of any terminological system. Undoubtedly this knowledge will help cope with the task of translation.

\section{References:}

1. Англо-русский железнодорожный словарь / Под. ред. А. Е. Чернухина; Сост. Р. Ф. Пронина, А. И. Бегун, Н. С. Волкова, Е. Мощук и др. М.: Трансжелдориздат, 1958. 662 с.

2. Гринев С. В. Введение в терминоведение. М.: Московский Лицей, 1993. 309 с.

3. Лейчик В. М. Терминоведение (предмет, методы, структура). Либроком, 2009. 256 с.

4. Морозова Л. А. Терминознание: Основы и методы. М.: ГНО «Прометей» МПГУ, 2004, 144 с.

5. Мямлін С. В., Власова Т. І., Купцова Т. А., Колієва І. А., Пустовойт Н. І. Тезаурус термінів залізничного транспорту (англійська, українська, російська, французька мови). Дн-вськ: Вид-во ПФ «Стандарт-Сервіс», 2016. 284 с. ISBN978-617-7382-02-6.

6. Русско-английский политехнический словарь. Под ред. Б. В. Кузнецова. Ок. 90,000 терминов. М.: Руссо, 2007. 728 с.

7. Ятель Г. П. Англійська мова (поглиблений курс) для студентів технічних вузів. Київ: «Вища школа», 1995, 382 с.

8. Cabré M. Teresa. Terminology. Theory, methods and applications. John Benjamins Publishing Company Amsterdam $\backslash$ Philadelphia, $1999,247 \mathrm{p}$.

9. Marchand H. Notes of English suffixation. Neuphilologische Mitteilungen. Helsinki, №. 5-6, 1953, pp. 254-267. 